UC.15

Issued: December 1982

\title{
Field Test and Evaluation of the IAEA Coincidence Collar for the Measurement of Unirradiated BWR Fuel Assemblies
}

\author{
H. O. Menlove \\ A. Keddar* \\ Particicants \\ H O Menlove. Los Alamos Natior al L aboratory \\ E Dahn. A. Keddar. A Kaleda. E. Woelfl. and E Weidl. \\ International Atomic Energy Agency. A-1400. Vienna. AUSTRIA \\ L Kiessing and $R$ Olsson. Swedish Nuclear Power inspectorate. Stockholm SWEDEN \\ $W$ Andersson and S. Jonsson. ASEA-ATOM. Vaesteraas. SWEDEN
}

NOTICE

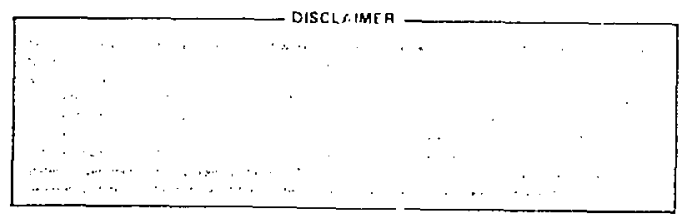

PORTIONS OF THIS REPORT ARE ILLEGIBLE. It

ras been reproduced from the best a a ailable

cony to parmit the broadest possiole avail-

ability.

- International Atomic Energy Agency. PO Box 100. A-1400. Vienna. AUSTRIA

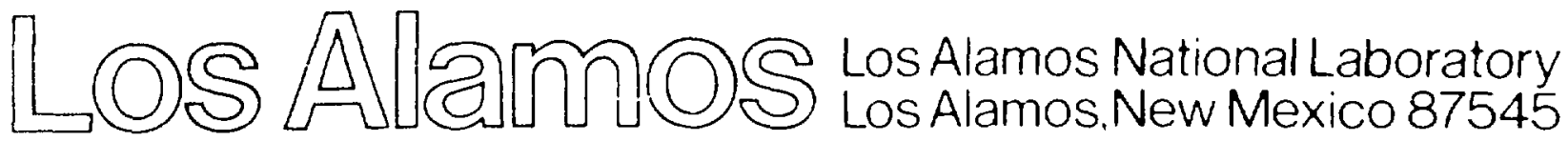




\section{CONTENTS}

ABSTRACT . . . . . . . . . . . . . . . . . 1

I. INTRODUCTION . . . . . . . . . . . . . . . . 1

II. DESCRIPTION OF FQUIPMENT AND SETUP . . . . . . . 2

A. Neutron Source............. 2

B. Measurement Setup ........... ?

C. Electronic Setup.............. 3

III. DESCRIPTION OF FUEL ASSEMBLIES . . • . . . . . . 3

A. Test Assemblies . . . . . . . . . . 3

B. Mockup Assembly ............... . 4

C. Rods Containing Gadolinium . . . . . . 5

IV. MEASUREMENT STEPS ............ 5

A. Initial Check-Out ............ 5

B. Routine Operation .......... . 8

V. IN-PLANT TEST RESULTS . . . . . . . . . . 8

A. In-Plant Neutron Background ....... 8

B. Response vs BWR Side Drientation ...... I

C. Response vs Enrichment or ${ }^{235}$ U Content.... 9

D. Passive Results ........... 13

E. Effects of Gadolinium Rods and Cadmium Sheet. 14

F. Production Assembly Results . . . . . . 15

G. End Effects ............. 15

H. $5 \times 5$ Rod Results ............. 17

I. Precision and Stability ........ 17

VI. CALIBRATION ......................... 18 
VII. CONCLUSIONS AND RECOMMENDATIONS ........ 21

A. E.lectrical Noise and Neutron Background . . 21

B. Precision and Stability ....... 22

C. Information Needed from Operator..... 2 ?

D. What is Obtained............. 22

E. Recommendations .......... 23

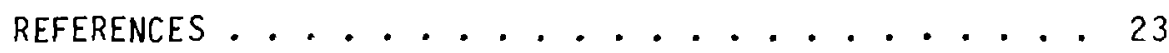

APPENDIX A: DATA COLLECTION AND STATISTICAL ANALYSES

PROGRAM USING THE HP-97 CALCULATOR . . . 24

APPENDIX B: CALIBRATION FOR $5 \times 5$ ROD ARRAYS ... 29 
FIELD TEST AND EVALUATION OF THE IAEA COINCIDENCE COLLAR FOR THE MEASUREMENT OF UNIRRAOIATEO BWR FUEL ASSEMBLIES

by

H. D. Menlove and A. Keddar

\begin{abstract}
The neutron coincidence counter has been field tested and evaluater for the measurement of boiling-water-reactor (BWR) fuel assemblies at the ASEA-ATON Fuel Fabrication Facility. The system measures the $235 \mathrm{U}$ content per unit length of full fuel assemblies using neutron interrogation and coincidence counting. The $238 \mathrm{U}$ content is measured in the passive mode without the AmL $i$ neutron interrogation source. The field tests included both standard production BWR assemblies and a full-size mockup assembly that had removable fuel rods to investigate enrichment and absorber variations. The results of the tests gave response standard deviation of $0.9 \%$ for the active case and $2.1 \%$ for the passive case in 1000-s measurement times.
\end{abstract}

\title{
I. INTROOUCTION
}

As part of the POTAS Procram Task A.75, three Class III Coincidence Collars have been supplied to the International Atomic Energy Agency (IAEA) for test and evaluation. This instrument can be used for the verification of unirradiated fuel assemblies either at the fuel fabrication facility or at the reactor site. Previnus reports ${ }^{1,2}$ have given a description of the Coincidence Collar and its application to PWR fuel assemblies. 
This report gives the results of the field test and evaluation of the Coincidence Collar (unit 3) for boiling-water-reactor (BWR) fuel assemblies. The measurements were performed at the ASEA-ATOM Fuel Fabrication Facility, Vaesteraas, Sweden, from November 12-17, 1981

The testing of the unit for BWR assemblies was of particular interest because of the presence of fuel rods with different ${ }^{235} \mathrm{U}$ enrichments and $\mathrm{Gd}_{2} \mathrm{O}_{3}$ burnable poisons in some of the rods in the assemblies. To check the effects of these parameters, the following tests were performed.

(1) Interrogate the assembly from each of the four different sides for comparison.

(2) Measure the vertical profile of the assembly.

(3) Change the ${ }^{235} \mathrm{U}$ loading and spatial configuration of the different enriched rods.

(4) Change the $\mathrm{Gd}_{2} \mathrm{O}_{3}$ rod loading.

(5) Change the number of normal rods.

In addition to the above measurements, the ease and time requirements for using the instrument in the plant environment were evaluated.

\section{DESCRIPTION OF EQUIPMENT AND SETUP}

A. Neutron Source

The present work used the IAEA Coincidence Collar-3, together with its source MRC-AmLi-93. This source has $0.66 \mathrm{Ci}$ of ${ }^{241}$ Am in the form of $\mathrm{AmO}_{2}$ with a neutron vield of $4.67 \times 10^{4} \mathrm{n} / \mathrm{s}$ and the IAEA Certification of Competent. Authority USA/D043/S.

B. Measurement Setup

A schematic diagram of the Coincidence Collar in its BWR geometric configuration is given in Fig. 1. For the measurements at ASEA-ATOM, the normal support cart for the collar was not used, because it was more convenient to set the collar directly on the elevated platform located three floors above the ground floor. This position is slightiy above the normal storage position of the fuel assembijes.

In this location, it was possible to lower the fuel assemblies through the coincidence collar and a hole in the floor using the overhead crane as shown 


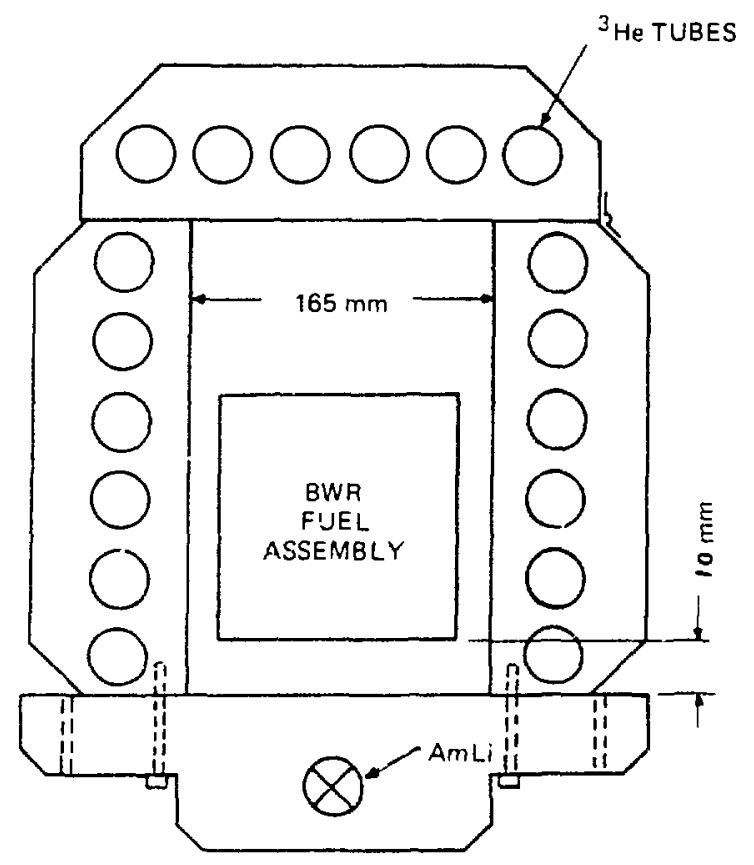

Fig. 1 .

Schematic diagram of Coincidence Collar set for BWR fuel assemblies.

in Fig. 2. Figure 3 shows a closer view of the measurement system with a BWR assembly in the measurement position. The assemblies were nomally measured inside their Zircaloy-2 water channel box and the plastic bag used to keep the assembly clean. The channel box was positioned approximately $1 \mathrm{~cm}$ from the front surface and sides of the Coincidence Collar.

\section{Electronic Setup}

The electronic components are identical to the High-Level Neutron Coincidence counter (HLNCC) described in Ref. 3. The recommended settings are

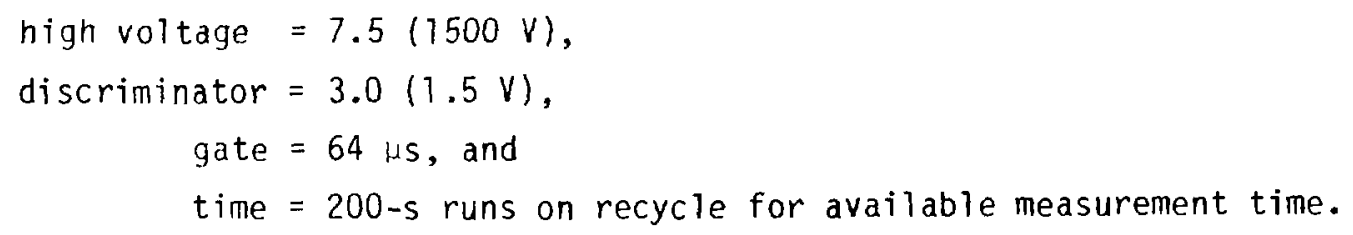

III. DESCRIPTION OF FUEL ASSEMBLIES

A. Test Assemblies

Two different types of normal production fuel assemblies were available at the time of the field test. In addition, a special mockup assembly was put 


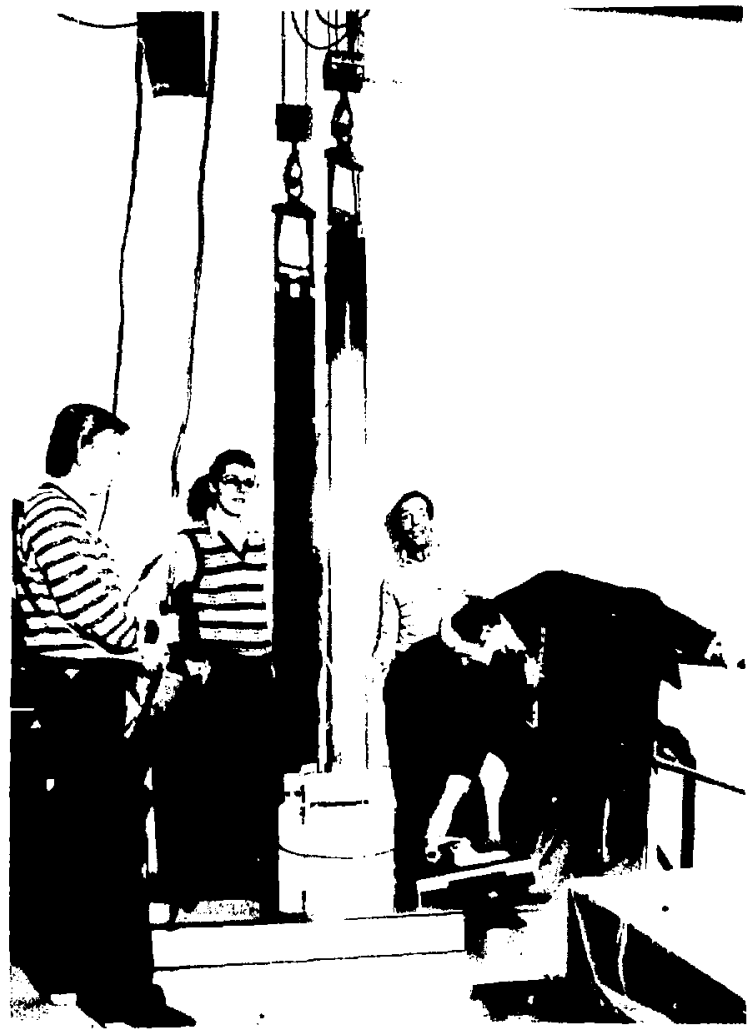

Fig. 2 .

Photograph of BWR fuel assembly being scanned through Coincidence Collar using the overhead crane at the ASEAATON facility. The detector head is positioned over a hole in the floor to accommodate the full length of the fue 1 assembly.

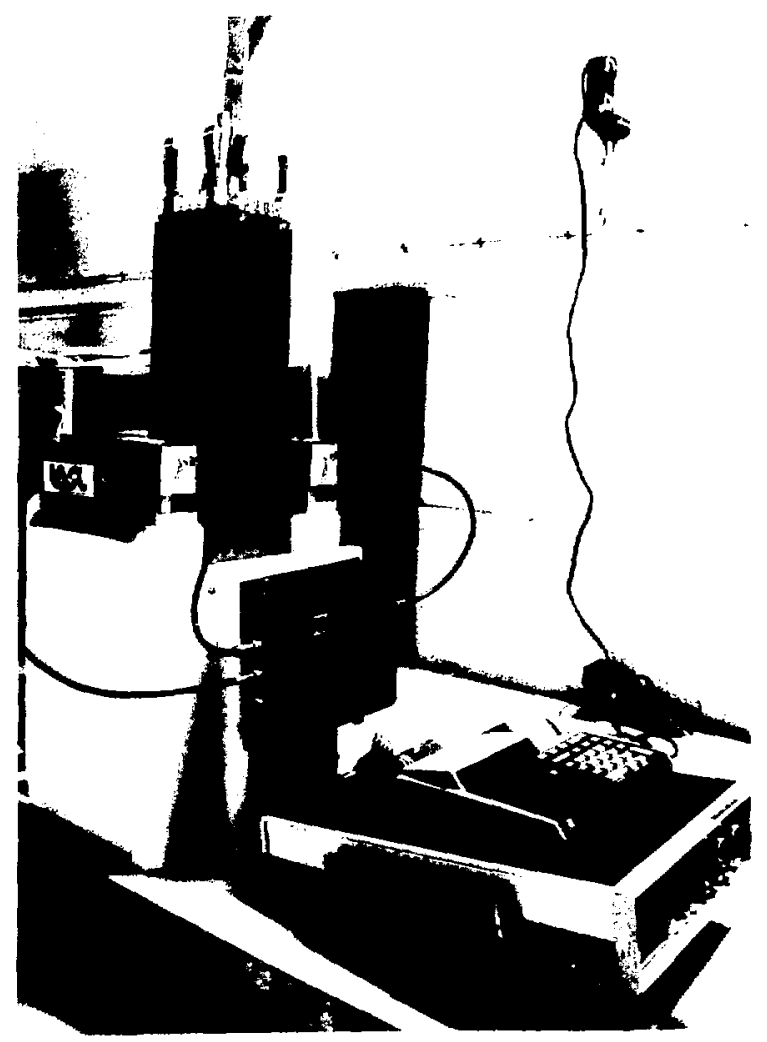

Fig. 3.

Close-up view of the Coincidence Collar and HLNCC electronics package. The BWR fuel assembly has the water channel box removed to show the fuel rods.

together to increase the flexibility of the evaluation. The normal assembly is an $8 \times 8$ rod array with one empty position resulting in 63 fuel rods. The characteristics of a typical fuel rod are given in Table $I$, and Table II gives a summary of the assemblies used in the evaluation. The $5 \times 5$ rod array was made up because there was interest in this size assembly within the Far East section of the IAEA.

\section{B. Mockup Assembly}

The mockup assembly was a full $8 \times 8$ array, 3.68-m-long assembly in a Zircaloy-2 or stainless steel channel box. The fuel rods could be removed to 
TABLE I

BWR FUEL ROD CHARACTERISTICS

$\begin{array}{ll}\text { Aciive length } & 3.630 \mathrm{~m} \\ \text { Pellet density } & 10.5 \mathrm{~g} / \mathrm{cm}^{3} \\ \text { Fellet diameter } & 9.94-10.44 \mathrm{~mm} \\ \text { Cladding o.d. } & 12.25 \mathrm{~mm} \\ \text { Cladding thickness } & 0.8 \mathrm{~mm} \\ \text { Cladding material } & \text { Zircaloy-2 } \\ \text { Assembly box } & \text { Zircaloy }-2\end{array}$

ohtain average enricinments ranging from 2.47 to $3.13 \%$. The configuration for the $2.85 \%$ average enrichment is shown in Fig. 4. The rods containing $\mathrm{Gd}_{2} \mathrm{O}_{3}$ are always located on the second or third rows in from the perimeter.

$\frac{\text { c. Rods Containing Gadolinium }}{\text { Typically, there are } 4 \text { to } 6 \text { rods }}$ in an assembly that contains 2-4.4 wt\% $\mathrm{Gd}_{2} \mathrm{O}_{3}$. This burnable neutron poison (gadolinium) is used to extend the useful 1 ife of the fuel assembly in the reactor for a given initial reactivity.
Figure 5 shows a schematic diagram of a rod containing $\mathrm{Gd}_{2} \mathrm{O}_{3}$. The vertical $\mathrm{Gd}_{2} \mathrm{O}_{3}$ profile is not uniform so that the burnup profile will flatten in the reactor. The two ends of the fuel rod contain little or no $\mathrm{gd}_{2} \mathrm{O}_{3}$ and the bottom section contains more $\mathrm{Gd}_{2} \mathrm{O}_{3}$ than the top section. This is to compensate for the reactivity loss from neutron leakage near the ends and the boiling water void fraction in the upper region of the reactor core.

\section{MEASUREMENT STEPS}

The measurement steps can be separated into the initial check-out and normal operation.

A. Initial Check-Out

(1) If the cart is to be used in the facility, attach the detector to the cart with thumbscrews.

(2) Check out the electronics as suggested in Ref. 3, and set the parameters as listed in Sec. II.C.

(3) Take a 100-s count with no AmLi source or fue? assembly near the unit. The net coincidence rate $(R+A)-A$, where $(R+A)$ is the reals plus accidentals and $A$ is the accidental rate, should be statistically equal to zero; the totals rate, $T$, should be between 10 and 600 counts/s, depending on the amount of $\mathrm{U}_{3} \mathrm{O}_{8}$ in the vicinity. 
TABLE II

BWR FUJEL ASSEMBLIES USED FOR COINCIDENCE COLLAR EVALUATION

\begin{tabular}{|c|c|c|c|c|c|c|c|}
\hline $\begin{array}{l}\text { Assembly } \\
\text { Type } \\
\end{array}$ & $\begin{array}{c}\text { Average } \\
\text { Enrichment }\end{array}$ & $\begin{array}{r}235 \mathrm{U} \\
(\mathrm{g} / \mathrm{cm}) \\
\end{array}$ & $\begin{array}{r}238 \mathrm{U} \\
(\mathrm{g} / \mathrm{cm}) \\
\end{array}$ & $\begin{array}{l}\text { Totaî } \\
\text { Rods } \\
\end{array}$ & $\begin{array}{r}\text { Rods } \\
\text { with } \\
\text { Gadolinium } \\
\end{array}$ & $\begin{array}{l}\mathrm{Gd}_{2} \mathrm{O}_{3} \\
(\mathrm{wt} \%) \\
\end{array}$ & $\begin{array}{c}\text { Assembly } \\
\text { Box }\end{array}$ \\
\hline Mockup A & $2.85 \%$ & 13.82 & 471.1 & 63 & 5 & 4.4 & $2 r-2$ \\
\hline B & $2.47 \%$ & 11.98 & 472.9 & 63 & 5 & 4.4 & $\mathrm{Zr}-2$ \\
\hline$C$ & $3.13 \%$ & 15.18 & 469.7 & 63 & 5 & 4.4 & $7 r-2$ \\
\hline D & $2.85 \%$ & 13.82 & 471.1 & 63 & 5 & 4.4 & $2 r-2$ \\
\hline$E$ & $2.85 \%$ & 13.82 & 471.1 & 53 & 3 & 4.4 & $2 r-2$ \\
\hline$F$ & $2.85 \%$ & 13.82 & 471.1 & 63 & 0 & 0 & $2 r-2$ \\
\hline
\end{tabular}

$\begin{array}{llllllll}5 \times 5-A & 3.12 \% & 5.76 & 178.9 & 24 & 0 & 0 & Z \mathrm{Zr}-2 \\ 5 \times 5-\mathrm{B} & 2.40 \% & 4.44 & 180.3 & 24 & 0 & 0 & \mathrm{Zr}-2\end{array}$

$\begin{array}{llllllll}T \cdot 1(a) & 2.91 \% & 14.11 & 470.8 & 63 & 6 & 4.4 & \mathrm{Zr}-2 \\ \mathrm{~T} \cdot 1(\mathrm{~b}) & 2.91 \% & 14.11 & 470.8 & 63 & 6 & 4.4 & \mathrm{Zr}-2 \\ \mathrm{~T} \cdot 1(\mathrm{c}) & 2.91 \% & 14.11 & 470.8 & 63 & 6 & 4.4 & \mathrm{Zr}-2\end{array}$

$\begin{array}{llllllll}T \cdot 2(\mathrm{a}) & 2.82 \% & 13.67 & 471.2 & 63 & 4 & 2.0 & \mathrm{Zr}-2 \\ \mathrm{~T} \cdot 2(\mathrm{~b}) & 2.82 \% & 13.67 & 471.2 & 63 & 4 & 2.0 & \mathrm{Zr}-2 \\ \mathrm{~T} \cdot 2 \text { (c) } & 2.82 \% & 13.67 & 471.2 & 63 & 4 & 2.0 & \mathrm{Zr}-2 \\ \mathrm{~T} \cdot 2 \text { (d) } & 2.82 \% & 13.67 & 471.2 & 63 & 4 & 2.0 & \mathrm{Zr}-2 \\ \mathrm{~T} \cdot 2(\mathrm{e}) & 2.82 \% & 13.67 & 471.2 & 63 & 4 & 2.0 & \mathrm{Zr}-2 \\ \mathrm{~T} \cdot 2(\mathrm{f}) & 2.82 \% & 13.67 & 471.2 & 63 & 4 & 2.0 & \mathrm{Zr}-2 \\ \mathrm{~T} \cdot 2(\mathrm{~g}) & 2.82 \% & 13.67 & 471.2 & 63 & 4 & 2.0 & \mathrm{Zr}-2\end{array}$




\begin{tabular}{|l|c|c|c|c|c|c|c|}
\hline 1.98 & 2.49 & 2.49 & 2.49 & 2.49 & 1.98 & 1.98 & 1.38 \\
\hline 2.49 & 3.37 & 3.17 & 3.50 & 3.37 & 2.49 & 2.49 & 1.98 \\
\hline 3.37 & 3.37 & 3.37 & 2.49 & 2.49 & 3.17 & 2.49 & 1.98 \\
\hline 3.37 & 3.50 & 3.37 & 1.38 & 1.38 & 2.49 & 3.37 & 2.49 \\
\hline 3.37 & 3.37 & 3.37 & $\times$ & 1.38 & 2.49 & 3.50 & 2.49 \\
\hline 3.37 & 3.37 & 3.37 & 3.37 & 3.37 & 3.37 & 3.17 & 2.49 \\
\hline 3.50 & 317 & 3.37 & 3.37 & 3.50 & 3.17 & 3.37 & 2.49 \\
\hline 2.49 & 3.37 & 3.37 & 3.37 & 3.37 & 3.37 & 2.49 & 1.98 \\
\hline
\end{tabular}

Fig. 4.

Diagram of the mockup $8 \times 8$ rod array (A) fuel assembly, where the numbers correspond to the $235 \mathrm{U}$ enrichment in the individual pins and $\mathrm{Ba}$ corresponds to a rod containing $\mathrm{GJ}_{2} \mathrm{O}_{3}$ burnable poison.

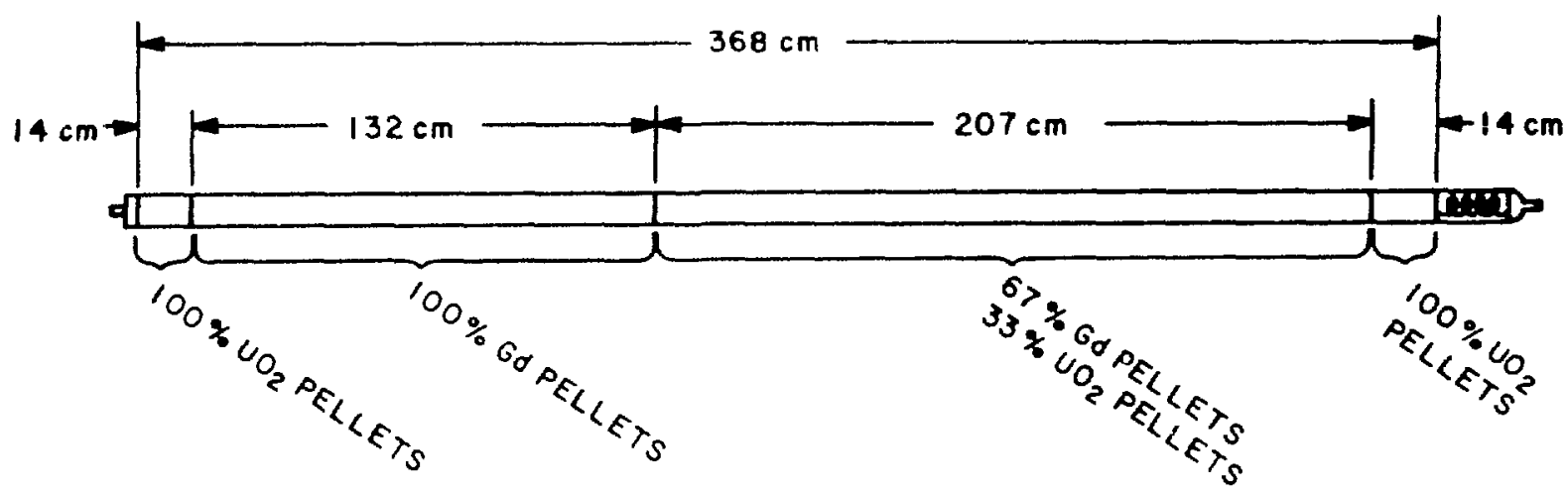

Fig. 5 .

Schematic diagram of the axial distribution of pellets in a typical rod containing gadolinium. 
(4) Place the AmLi source in its normal position in the polyethylene detector (see Fig. 1) and observe (100-s run) that the net coincidence rate is statistically zero. The net totals rate should be 22160 counts/s (BWR detector geometry), depending on the AmLi source strength.

(5) Temporarily remove the AmLi source from the unit and position the Coincidence Collar around a fuel assembly. Take a longer ( $300-s)$ count to determine the fuel assembly coincidence background rate. This should be 23 counts/s for the net coincidence counts for BWR assemblies. This number depends primarily on the $238_{U}$ mass and is approximately the same for all of the fuel assemblies of the same mass. It will be subtracted from the induced coincidence counts in the data reduction.

\section{B. Routine Operation}

(1) Passive mode (no AmLi) - set the time for 200-s recycle and press the start button on HEC-100 electronics.

(2) After the desired number of cycles $(2-3)$, press the stop button on HEC - 100 and the program key $B$ on the HP-97. This will print out the passive results and store the background data for the active assay.

(3) Active mode (with AmLi) - press the start button on HEC-100 to start the 200-s runs.

(4) After the desired number of 200-s cycles (25), stop the run and press the program key $C$ on the HP-97. This will print out the active results.

\section{IN-PLANT TEST RESULTS}

\section{A. In-P1ant Neutron Background}

The in-plant neutron background measured at the test station was very low. The totals rate was about 20 counts/s, which is an order of magnitude lower than that measured in pressurized-water-reactor (PWR) fabrication facilities. This is because we were about $10 \mathrm{~m}$ away from the fuel storage location. The coincidence background was statistically equal to zero. The totals rate from a single BWR assembly inside the Coincidence Collar gave a rate of roughly 
45 counts/s. This value was entered into the software program given in Appendix $A$ to make the small passive neutron correction to the coincidence rate. Table III lists the backgrounds and source rates for the tests.

\section{B. Response vs BWR Side Orientation}

As seen in Fig. 4, there are normally several different enrichments in a single BWR fuel assembly and these are nonsymmetric as viewed from the difierent sides. To see if this affects the response, the assembly was measured on all four sides and the results were compared. No differences were observed in the responses within the measurement precision of $\pm 1 \%$.

Previous measurements ${ }^{1}$ using a BWR mockup assembly at Los Alamos National Laboratory had indicated that the response from the Coincidence Collar was independent of the position of rods of different enrichments in the assembly. However, the measurement does depend on the number and position of the gadolinium rods. Because the gadolinium rods are always placed in the interior of the BWR assemblies, roughly equidistant from each other, the measured response was the same for all sides of the fue? assembly with the gadolinium rods in place.

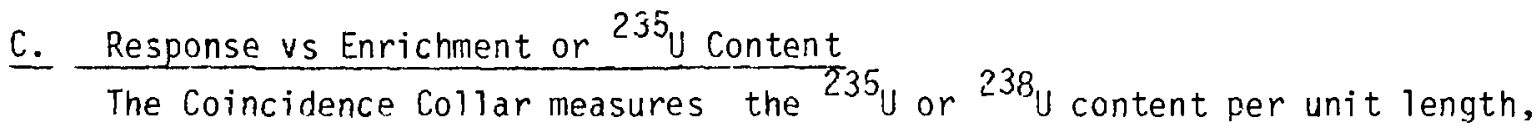
which is proportional to the enrichment for a given type of assembly. The sampled region is approximately $400 \mathrm{~mm}$ long centered in the midplane of the detector body. If the edge of the detector body gets closer than $20 \mathrm{~cm}$ to the top

\section{TABLE II I}

IN-PLANT NEUTRON BACKGROUNO LEVELS

\section{Condition}

Room background (third floor) Single BWR assembly (no AmLi)

AmLi-93 (no fuet assembly)

BWR (2.82\%) assembly (bott'sm)
Totals Rate

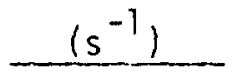

20

45 (net)

2160

2350 (gross)
Coincidence Rate

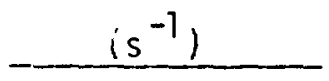

0

3.2

0

86.3 
or bottom ends of the fuel region, the measured response will decrease because of end leakage of the neutrons. Any region selected inside these end regions should give a constant counting rate if the ${ }^{235} \mathrm{U}$ loading and $\mathrm{Gd}_{2} \mathrm{O}_{3}$ is uniform. When an overhead crane is available for scanning the fuel assembly through the detector, then the entire assembly can be sampled. The measurement time is the same for the scanning or stationary modes with equivalent statistical precision. If the scanning mode is used, the calibration curve should be obtained in the same manner to take into account the end losses as the assembly enters and leaves the detector. The ccunting rate in a given section of the assembly is the same for both the scanning or stationary modes of operatior:

The measurements on each assembly were performed using several runs of $200 \mathrm{~s}$ each depending on available time. No personnel were required to be in attendance during the cyclic measurements. For each assembly, the measurements were performed both with and without the AmLi source to obtain both the $235:$ and 238 u values.

The results of the measurements are listed in Table TV for the active ne:tron case using Coincidence Collar-3. Typically, five runs of $200 \mathrm{~s}$ pach werp used to obtain the results; however, some of the elements were measureo for longer periods corresponding to lunch breaks ano overnight runs. All nf the assemblies listed in Table I I were measured during the test. The average not coincidence response and the scatter (standard deviation, s) about the mean are listed in Table IV. Table $V$ gives the coincidence results for the mockup fupl as semblies.

A least squares fit was made to the mockup coincidence data using a quadratic function. This function was then used to obtain the 23511 enrichments of the production assemblies listed in nle IV. Details concerning the calibration curve and the quadratic function parameters are given in Sec. VI.

Figure 6 shows the coincidence response as a functiun or enrichment for the active case. The response increases with enrichment and is not saturated. This is due, in part, to fast neutron multiplication. There is no significant variation as a function of assembly storage location ind the proximity of neighboring assemblies.

The gadolinium loading in the BWR asseliblies decreases the observed response. Also, the gadolinium concentration is higher in the bottom half of the fuel assemblies than in the top. The two curves shown in Fig. 6 correspond to the top and bottom regions. The separation in the two curves is a measure of the number of gadolinium-loaded rods. 
TABLE IV

ACTIVE ASSAY OF BWR FUEL ASSEMBLIES

\begin{tabular}{|c|c|c|c|c|c|c|}
\hline \multirow[b]{2}{*}{ Assembly } & \multirow[b]{2}{*}{$\begin{array}{c}A v \\
235 u \\
\end{array}$} & \multirow{2}{*}{$\begin{array}{l}\text { Run } \\
\text { Time } \\
(\mathrm{s}) \\
\end{array}$} & & \multicolumn{3}{|c|}{ Coincidence Rate } \\
\hline & & & & $\begin{array}{l}\text { Top } \\
(\mathrm{s}-1)\end{array}$ & & $\begin{array}{r}\text { Bottom } \\
(\mathrm{s}-1)\end{array}$ \\
\hline$T \cdot 1(a)$ & $2.91 \%$ & $3 \times 200$ & & $82.42 \pm 1.07$ & & $77.47 \pm 1.09$ \\
\hline$T \cdot 1(b)$ & $2.91 \%$ & $5 \times 200$ & & $82.44 \pm 0.80$ & & $77.50 \pm 0.77$ \\
\hline \multirow[t]{5}{*}{$T \cdot 1(c)$} & $2.91 \%$ & $10 \times 200$ & & $\underline{83.29} \pm 0.62$ & & $\underline{77.27} \pm 0.58$ \\
\hline & & & $x$ & $=82.72$ & $x=$ & $=77.41$ \\
\hline & & & $\mathrm{S}$ & $=0.50$ & $s=$ & $=0.13$ \\
\hline & & Assay Value ${ }^{a}$ & & $=2.93 \%$ & & $2.85 \%$ \\
\hline & $\%$ diff. & $\frac{\text { Meas. }- \text { Tag }}{\text { Tag }} \times 100$ & & $=0.69 \%$ & & $-1.71 \%$ \\
\hline$i \cdot 2(a)$ & $2.82 \%$ & $7 \times 200$ & & -- & & $85.30 \pm 0.74$ \\
\hline$T \cdot 2(b)$ & $2.82 \%$ & $5 \times 200$ & & $90.00 \pm 0.90$ & & $84.72 \pm 0.80$ \\
\hline$T \cdot 2(c)$ & $2.82 \%$ & $6 \times 200$ & & $88.93 \pm 0.89$ & & $85.80 \pm 0.51$ \\
\hline$T \cdot 2(d)$ & $2.82 \%$ & $5 \times ? 00$ & & -- & & $87.29 \pm 0.87$ \\
\hline$T \cdot 2(e)$ & $2.82 \%$ & $10 \times 200$ & & $\cdots$ & & $87.85 \pm 0.62$ \\
\hline$T \cdot 2\langle f\rangle$ & $2.82 \%$ & $10 \times 200$ & & $-\cdots$ & & $86.91 \pm 0.70$ \\
\hline \multirow[t]{5}{*}{$T \cdot 2(g)$} & $2.82 \%$ & $9 \times 200$ & & -- & & $86.20 \pm 0.70$ \\
\hline & & & $x=$ & $=89.47$ & $x=$ & 86.30 \\
\hline & & & & & $S=$ & 1.12 \\
\hline & & Assay value ${ }^{a}$ & $=$ & $=2.83 \%$ & & $2.83 \%$ \\
\hline & $\%$ diff. & $\frac{\text { Meas }- \text { Tag }}{\text { Tag }} \times 100$ & $=$ & $=0.35 \%$ & & $0.35 \%$ \\
\hline
\end{tabular}

aAssay value from calibration curve for mockup assembly after correction for differences in $\mathrm{Gd}_{2} \mathrm{O}_{3}$ loading. 
DATA SUMMARV FOR HOCKUP FUEL ASSEMBLIES

\begin{tabular}{|c|c|c|c|c|c|c|c|c|}
\hline \multirow{2}{*}{\multicolumn{2}{|c|}{ Assembly }} & \multirow{3}{*}{$\begin{array}{r}\hat{A v} \\
235 U \\
2.85\end{array}$} & \multirow{3}{*}{$\begin{array}{r}\text { Gd } \\
\operatorname{Rods} \\
5\end{array}$} & \multirow[b]{2}{*}{$\begin{array}{l}\text { Run } \\
\text { Time (s) }\end{array}$} & \multicolumn{4}{|c|}{ Comcraence Rale } \\
\hline & & & & & & \multicolumn{2}{|c|}{$\begin{array}{r}\text { Bottom } \\
\left(\mathrm{s}^{-1}\right)\end{array}$} \\
\hline \multirow[t]{6}{*}{ Mockup } & $A$ & & & $5 \times 200$ & 83.97 & +0.84 & 30.83 & $\cdot 0.81$ \\
\hline & B & 2.47 & 5 & $5 \times 200$ & 76.64 & +0.77 & 73.41 & -0.73 \\
\hline & C & $3.13^{\circ}$ & 5 & $5 \times 200$ & 91.25 & +0.91 & 36.75 & \pm 0.87 \\
\hline & D & 2.85 & 5 & $5 \times 200$ & 83.97 & $\cdot 0.84$ & 80.83 & $\cdot 0.81$ \\
\hline & $E$ & $2.85^{\prime \prime}$ & 3 & $5 \times ? .00$ & & -- & 91.41 & +0.91 \\
\hline & $F$ & $2.85^{\prime \prime}$ & 0 & $10 \times 200$ & & -- & 105.3 & $\cdot 0.20$ \\
\hline$(C D)$ & $F$ & 2.85 & 0 & $6 \times 10000$ & & -- & 8.4 & +0.08 \\
\hline$(C D)$ & 0 & $2.85=$ & 5 & $9 \times 500$ & & $-\cdots$ & 7.4 & .0 .20 \\
\hline$(C D)$ & $T \cdot 2$ & 2.82 & 4 & $13 \times 500$ & & - & 7.8 & +0.11 \\
\hline $5 \times 5$ & G & $3.12:$ & 0 & $6 \times 10000$ & - & -- & 51.35 & \pm 0.12 \\
\hline $5 \times 5$ & $H$ & 2.40 & 0 & $13 \times 600$ & - & - & 42.12 & .0 .34 \\
\hline
\end{tabular}

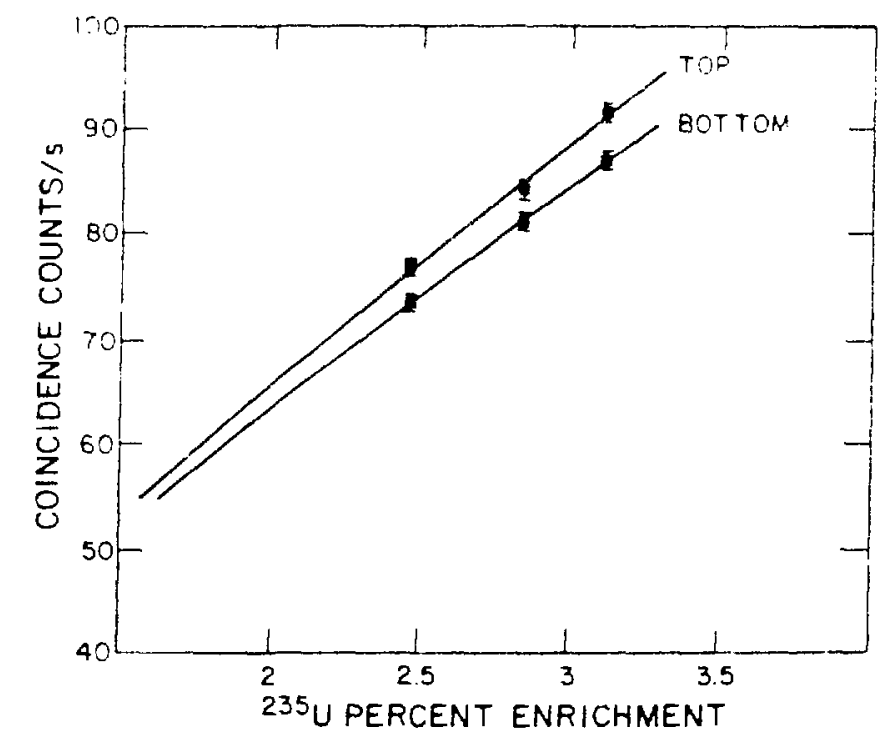

Fig. 6 .

Active measurements results for different average enrichments in the mockup fuel assemb1y. The top and bottom curves correspond to the top and bottom regions of the fuel assembly with different $\mathrm{Gd}_{2} \mathrm{O}_{3}$ loadings. 
D. Passive Results

When the AmL; source is removed from the detector, the passive coincidence rate is proportional to the $238 \mathrm{U}$ mass by means of the spontaneous fission neutrons. For the $8 \times 8$ BWR assemblies, the uranium mass and the enrichment did not change enough to significantly change the passive response, which was 3.78 counts/s. Because this is only a small fraction of the active response that ranges from 80 to 100 counts/s, the passive rate was not measured for each of the assemblies, and the constant rate (3.18) was subtracted from the active rate to get the net active rate.

When the uranium mass or rods are removed from the assembly, the passive rate drops because of the reductions in the $238 \mathrm{U}$ source strength and in the fast-neutron multiplication and because of the decrease in the reflection of neutrons from the top and bottom of the measul wient, zone. Figure 7 plots the passive coiplcidence response for both the $8 \times 8$ (63 rods) and $5 \times 5$ (24 rods) assemblies. Also shown on

the plot is a data point for a $6 \times 6$ rod assembly that was measured at Los Alanios before shipping Coiricidence collar-3 to the agency.

The statistical ?recision for the $8 \times 8$ assembly was $1.8 \%$ for $1000 \mathrm{~s}$ of run time in the passive mode. The gadolirium rods do not affect the passive measurement; because the siynal is from fast fission neutrons, the thermal neutron absorber (yadolinium) has no effect.

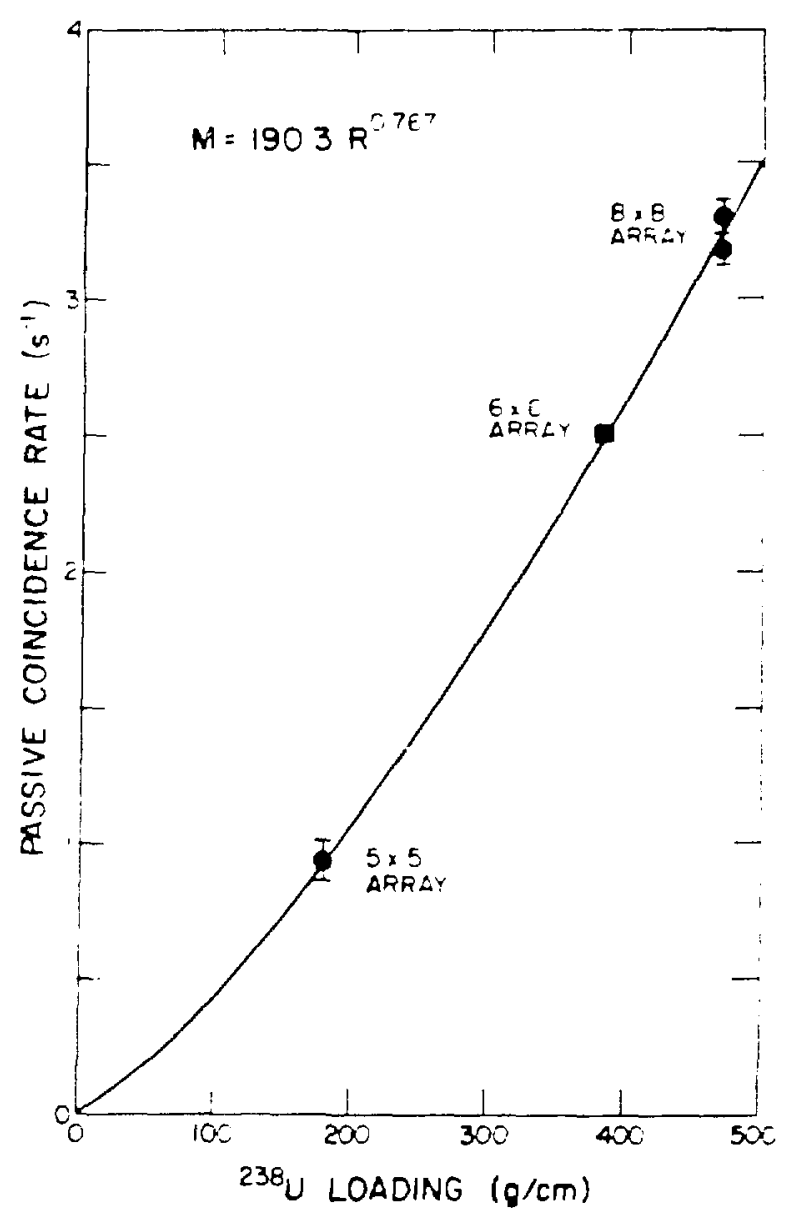

Fig. 7 .

Passive measurement results for nockup assemblies containing different numbers of fuel rods. The data for the $6 \times 6$ array were taken at Los Alamos before the ASEA-ATOM exeruise. 
To evaluate the effect of the rods containing gadolinium on the active response, the $8 \times 3$ mockup assembly was changed to contain 5, 3, and 0 gado1 inium rods. In each case, the gadoliniun rod was replaced by a rod containing the same ${ }^{235} \mathrm{U}$ enrichment $(3.17 \%)$ but without gadolinium. The results of the active measurements are shown in Fig. 8, where we see that one gadolinium ( $4.4 \mathrm{wt}_{2} \mathrm{Gd}_{2} \mathrm{O}_{3}$ ) rod reluces the active response by about $5 \%$. For a rod containing less $\mathrm{Cr}_{2} \mathrm{O}_{3}$ (for example, 2 wt.), the reduction is a little less but the effect is nonlinear with $\mathrm{Gd}_{2} \mathrm{O}_{3}$ mass because the rods are nearly "black" or saturated for thermal neutron absorption.

The perturbation on the measurement from the $\mathrm{Gd}_{2} \mathrm{O}_{3}$ can be mostly eliminated by using thin cadmium sheet, liners $(0.4 \mathrm{~mm}$ thick) on the inside surface of the sample chamber. The cadmium removes the thermal neutrons from the interrogation flux and thus the thermat neutron poison $\left(\mathrm{Gd}_{2} \mathrm{O}_{3}\right)$ has no significant effect. The bottoin curve in Fig. 8 shows that there is little difference in the responses with zero or five $\mathrm{Gd}_{2} \mathrm{O}_{3}$ rods when the cadmium sheet is in place.

However, the cadmium reduces the signal rate, and thus the measurement time to reach a given precision is increased. For example, the standard deviation with cadmium is $4.0 \%$ in $1000 \mathrm{~s}$ as compared with $0.9 \%$ in $1000 \mathrm{~s}$ with no cadmium. Because the cadmium increases the required measurement time, it should be used only as a

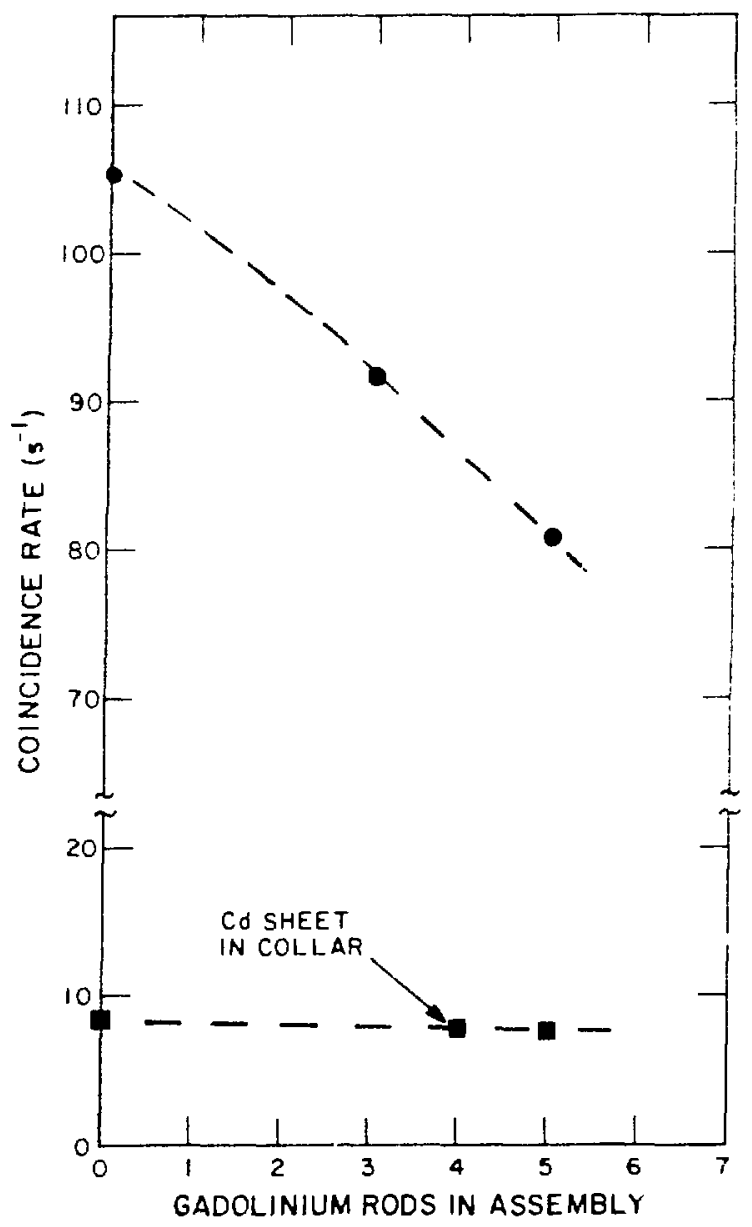

Fig. 8.

Coincidence rate as a function of the number of $\mathrm{Gd}_{2} \mathrm{O}_{3}$ rods both with (bottom curve) and wi thout (top curve) a cadmium liner on the inside of the collar. 
potential check on the operator-declared gadolinium content and not for routine use.

Because the gadolinium loading is greater in the bottom than in the top half of the assembly, the bottom-to-top ratio gives a second potential check on the gadnlinium content. For example, if the $\mathrm{Gd}_{2} \mathrm{~J}_{3}$ were removed tc give a higher reading for the average ${ }^{235} \mathrm{U}$ enrichment, then the bottom and top measurentents would be the same, as opposed to the normal difference of $25 \%$ as shown in Fig. 6 .

\section{F. Production Assembly Results}

Two types of production assemblies were available for the tests; type 1 coritaining six rods with $4.4 \mathrm{wt}^{\prime \prime} \cdot \mathrm{Gd}_{2} \mathrm{O}_{3}$, and type 2 containing folir rods with 2.0 wt: $\mathrm{Gd}_{2} \mathrm{O}_{3}$. Several of these assemblies were measured as shown in Table IV. The responses showed a scatter of $.1 \%$, which is consistent with the statistical expectations for measurement times of 800 to $1000 \mathrm{~s}$. If shorter measurement times are desired, the precision will increase as the square root of the tine. For example, a 300-s measurement will give a standard deviation of $21.7 \%$.

The calibration results from the mockup assembly were used to assay the production assemblies. A least squares fit was made to the data for top and botton zones to establish the two calibration curves shown in Fig. 9. The measured data from the production assemblies were then corrected for the differences in $\mathrm{Gd}_{2} \mathrm{O}_{3}$ using $\mathrm{Fig}$. 8, and the responses were fit to the mockup calibration curves (Fiq. 9) to determine the ${ }^{235} \mathrm{U}$ content. The average difference between collar assay value and the tag value was $0.6^{*}$, for the $T \cdot 1$ type assemblies and $0.35 \%$ for the $T \cdot 2$ assemblies.

\section{G. End Effects}

Measurements were performed to determine the "end effects" when the fuel assembly is scanned completely through the coincidence Collar. The overhead crane was used to move the fuel assembly in increments of $10 \mathrm{~cm}$ near the top and bottom ends of the fuel assembly.

The results of the measurement are shown in Fig. 10, where the coincidence response corresponds to assembly $T \cdot 2$ for the top measurement and mockup $A$ assembly for the bottom region. To avoid end effects, the top or bottom of the collar should not get closer than $15-20 \mathrm{~cm}$ to the ends of the active fuel region. 


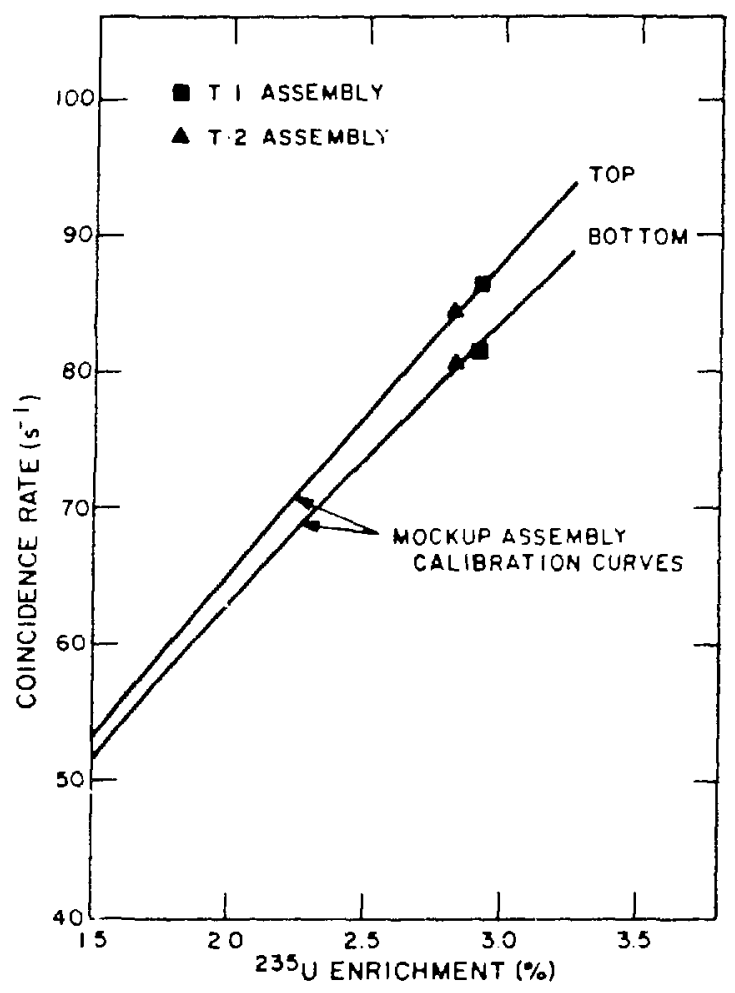

Fig. 9.

The results from the production assembly measurements compared with the calibration curves obtained from the mockup assembly.

Fig. 10.

Axial scans of the mockup as sembly (A) and the production assembly $(T \cdot 1)$ near the bottom and top ends of the active fuel $\left(\mathrm{UO}_{2}\right)$ regions. The slight rise in the response near the end is caused by the absence of $\mathrm{Gd}_{2} \mathrm{O}_{3}$ in the last $14 \mathrm{~cm}$ of the fuel column.

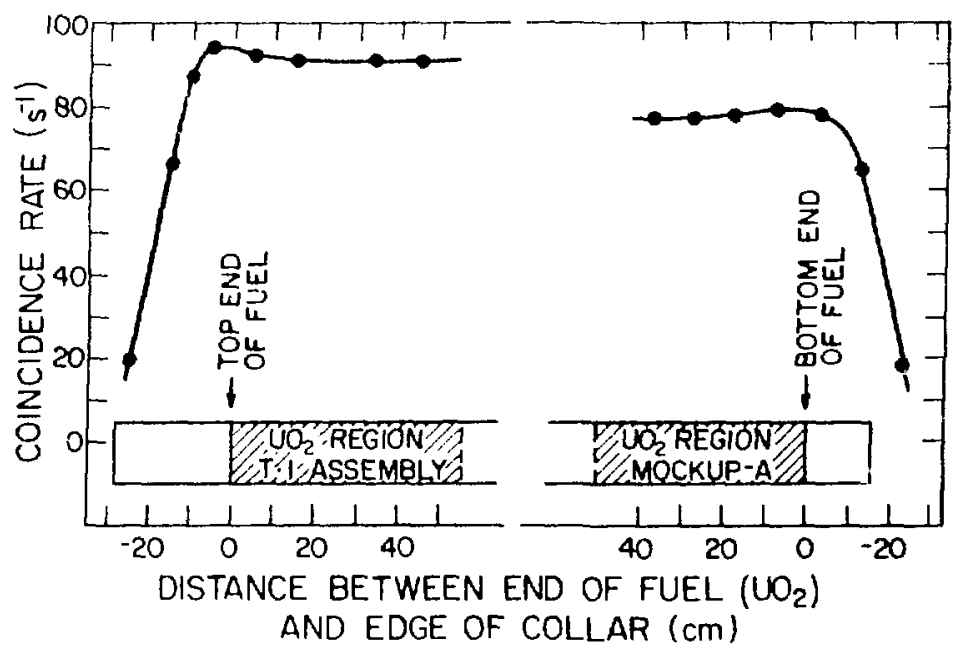


For fuel assemblies with no gadolinium in the pellets near the ends of the rod, the end response shows a slight increase before dropping off when the fue 1 ends. This effect first alerted us to the variable loading along the length of the gadolinium rods.

H. $5 \times 5$ Rod Results

The $5 \times 5$ rod loading is not a normal BWR configuration, but BWR rods stored in this confi iuration are under IAEA safeguards. Because of the atypical nature of this configuration, the results are detailed in Appendix $B$.

I. Precision and Stability

To check the stability and precision of the system, long runs were performed overnight and during the weekend. The results of the long-term stability checks are given in Table VI. No electrical noise was observed in the system during the in-plant tests.

The predicted standard deviation (o) is calculated from the expression

$$
v=\frac{\sqrt{(R+A)+A}}{R} \times 100 \%
$$

The software program calculated the mean and the standard deviation $S$ from the observed scatter about the mean.

The observed scatter is about $0.1 \%$ higher than the predicted $\sigma$ from counting statistics, which is consistent with previous measurements under $1 a b-$ oratory test conditions.

TABLE VI

IN-PLANT STABILITY AND PRECISION MEASUREMENTS

\begin{tabular}{lcccc} 
Assembly & \multicolumn{2}{c}{ Run Time } & \multicolumn{2}{c}{ Standard Deviation (Coinc.) } \\
Mockup A & $15 \times 4000 \mathrm{~s}$ (overnight) & $0.63 \%$ & $0.52 \%$ \\
$\mathrm{~T} \cdot 2$ & $15 \times 4000 \mathrm{~s}$ (overnight) & $0.59 \%$ & $0.49 \%$ \\
Mockup B & $24 \times 10000 \mathrm{~s}$ (weekend) & $0.43 \%$ & $0.35 \%$
\end{tabular}


The active assay data for the different enrichments are shown in Fig. 6 . To take advantage of HP-97 software programs used with the HLNCC, ${ }^{3}$ a quadratic function was used to fit the data.

$$
M=A_{0}+A_{1} R+A_{2} R^{2},
$$

where $R$ is the coincidence response, $M$ is the fissile content per unit length (or enrichment), and $A_{0}, A_{1}$, and $A_{2}$ are constants.

For the top region, the constants determined from fitting the data from Coincidence Collar-3 for the $8 \times 8$ rod mockup BWR assembly (5 rods with $\mathrm{Gd}_{2} \mathrm{O}_{3}$ ) are given.

$$
\left.\left.\begin{array}{l}
A_{0}=-0.523 \\
A_{1}=0.03458 \\
A_{2}=0.0000616
\end{array}\right\} \begin{array}{c}
235 \text { enrichment } \\
\text { (top zone) } \\
A_{0}=-2.535 \\
A_{1}=0.1576 \\
A_{2}=0.000299
\end{array}\right\} \quad \begin{gathered}
235 \text { grams per cm } \\
\text { (top zone) }
\end{gathered}
$$

These two sets of constants are related by the ratio of

$$
\frac{13.67 \mathrm{~g}^{235} \mathrm{U} \text { per } \mathrm{cm}}{2.82 \%}=4.848 \text {. }
$$

Thus, if one fits for the enrichment, the ${ }^{235} \mathrm{U}$ mass per centimeter can be determined by multiplying by 4.848 for this particular type fuel assembly. The 
advantage of using the mass per unit length is that one assembly type can be related to other assembly geometries (for example, $7 \times 7$ arrays). The advantage of using the enrichment is that enrichment data are normally supplied by the operator during inspection.

The constants listed above Here determined froln a least squares fit of the data, where we inserted a point near zero $235 \mathrm{U}$ enrichment $(0.01 \%)$ of 14 counts/s. This was estinated from theoretical considerations of the fast neutron fissions in the ${ }^{239} \|$ mass. The reason for the artificial data point was to better anchor the quadratic function near the zero ${ }^{235} \mathrm{U}$ mass end, and thus to reduce the uncertainties in the calibration curve.

For the bottom region, we give the corresponding constants.

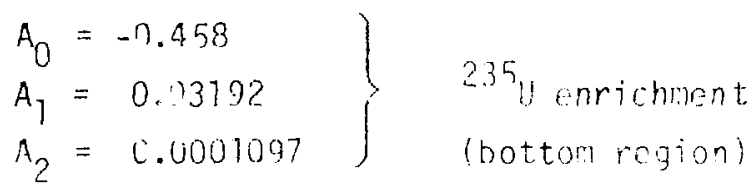

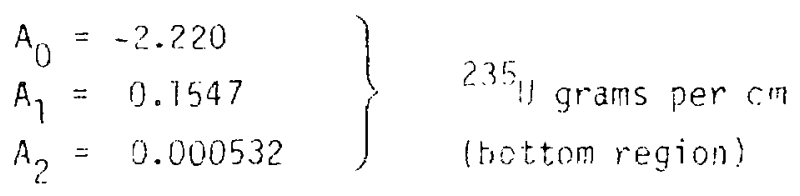

The above calibration constants correspond to $8 \times 8$ rod assemblies (63 rods) containing five rods loaded with $\mathrm{Gd}_{2} \mathrm{O}_{3}(4.4 \mathrm{wt})$. For applications to assemblies with different gadolinium loadings, it is necessary to correct the measured response using the curve in Fig. 8. The gadolinium rod loadings are normally the same for all the assemblies in a given reactor core loading.

Any future measurements of BWR assenblies with Coincidence Collar-3 can be related to the above calibration parameters by using the AmLi source norma1ization procedure described in Ref. 1. By counting the net $T$ for AmLi-93 (no fuel in counterl at the time of calibration, future electronic shifts in the rates can be corrected by again counting the same AmLi source.

For the present exercise, the AnLi-93 rate is

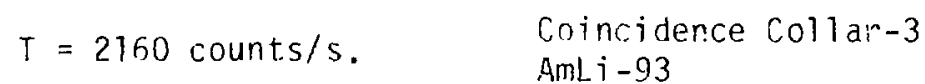


The corresponding enrichment is given by

$$
M=A_{0}+A_{1} R+A_{2} R^{2}
$$

where the $A^{\prime} s$ are the calibration constants and $R$ is the net coincidence rate in counts per second.

The normalization constant is defined as

$$
k=\left[\frac{T(\text { origina }))}{T(\text { current })}\right]^{2},
$$

or

$$
k=\left[\frac{2160}{\text { T(current })}\right]^{2} \text {, }
$$

and

$$
R_{\text {(Norm) }}=k R_{\text {(current) }} .
$$

The enrichment of an unknown BWR assembly can be calculated from the equation

$$
M=-0.458+0.03192(k R)+0.0001097(k R)^{2}
$$

for the bottom region of the fuel assembly. Similarly, the top region calibration constants are used for measurements in the top fuel region. Normally, 
only the bottom region of the assembly would be measured, with the inspector checking the top region if additional verification of the gadolinium loading seemed warranted.

\section{Example Calculation. (Hypothetical future data)}

Net totals rate $=2040$ counts $/ s$ (source alone)

Coincidence rate $R=81.0$ counts $/ \mathrm{s}$ (bottom region of assembly)

Number of $\mathrm{Gd}_{2} \mathrm{O}_{3}(4.4 \mathrm{wt} \%$ ) rods $=4$ (vs 5 for calibration parameters)

Reduce the response by $81.0 / 1.05$ for the yadolinium difference (4 vs 5 rods)to get $R$ (gadolinium $C$ i.r.) $=77.14$ counis/s. Next, to account for the electronic shift, calculate

$$
k=\left[\frac{2150}{2040}\right]^{2}=1.121
$$

Then the enrichment is

$$
i=0.458+0.03192(k R) \quad 0.0001097(k R)^{2}
$$

or

$$
M=3.12 \% 235 \mathrm{U}
$$

In general, this calculation will be automated in the HP-97 calculator.

VII. CONCLUSIONS AND RECOMMENDATIONS

\section{A. Electrical Noise and Neutron Background}

No electrical noise or interference problems were observed at the plant. The collar had properly shielded cables and there was fresh desiccant in the hv boxes. 
Room neutron levels were small and interfered with neither the active nor passive measiurements. There were no problems in measuring the passive coincidence signal to check the $238 \mathrm{U}$.

B. Precision and Stability

1. Active Assay for ${ }^{235} \mathrm{U}$. The statistical precision for a $1000-\mathrm{s}$ run was $20.9 \%(10)$. For longer counting periods of $27 \mathrm{~h}$, the precision was about $0.4 \%$.

2. Passive Results for ${ }^{238} \mathrm{U}$. The counting rates for the passive measurements are much lower than for the active case. The statistical standard deviation was $23.3 \%$ (400 s).

C. Information Needed from Operator

(1) Number of gadolinium rods, wt\% $\mathrm{Gd}_{2} \mathrm{O}_{3}$, and axial distribution

(2) Average ${ }^{235} \mathrm{U}$ enrichment of fuel assembly

(3) Active length of fuel region

D. What is obtained

(1) Uraniuim-235 enrichment (or $235 \mathrm{U} / \mathrm{cm}$ ) relative to calibration with same type assembiy $(10=1 \%$ in $800 \mathrm{~s})$ or $(1.4 \%$ in $400 \mathrm{~s})$.

(2) Absolute ${ }^{235} U$ enrichment by fitting to general calibration curve for $8 \times 8$ assembly plus gadolinium correction. (10 $22-3 \%$ in $400 \mathrm{~s})$.

(3) Check on $\mathrm{rdd}_{2} \mathrm{O}_{3}$ content by ratio of top to bottom.

(4) Absolute ${ }^{238} \mathrm{U}$ content by rissive count. $(10 \% 3.3 \%$ in $400 \mathrm{~s})$ independent of gadolinium loading.

(5) Results do not depend on enrichment configuration or peliet density.

(6) Results do not depend on plastic bagging or Zircaloy channel; however, the stainless steel storage channels significantly $(12 \%)$ reduce the response.

(7) For fixed average enrichment, the number of gadolinium rods can be determined in 300 to $400 \mathrm{~s}$. 


\section{E. Recommendations}

Assemblies that differ from the present assemblies can still be measured to obtain the relative loading of a group of fuel assemblies. Repeat measurements over a period of time verify that the assemblies have not been tampered with. Assemblies that differ from the calibration assemblies are still measured using the inappropriate calibration curve, but the uncertainty in the absolute result will be somewhat larger. Calculations are performed to reduce this uncertainty.

(1) For routine measurements, some fabrication facilities will require a custom-built cart or support mechanism for the collar.

(2) Coincidence Collar-3, together with AmLi source MRC-AmLi-93, is calibrated for the verification of BWR fuel assemblies.

(3) In general, each major category of fuel (for example, PWR and BWR) will require its own calibration curve. Within a fuel assembly category such as BWR, there are variations such as rod number in the array $(6 \times 6$ to $8 \times 8)$ and fuel rod diameter, which will require small corrections to the calibration curves. These correction factors should be calculated, for most cases, using Monte Carlo computer codes to avoid excessive costs in physical standards preparation.

\section{REFERENCES}

1. H. 0. Menlove, "Description and Performance Characteristics for the Neutron Coincidence Collar for the Verification of Reactor Fuel Assemblies," Los Alamos National Laboratory report LA-8939-MS (ISP0-142) (1981).

2. H. 0. Menlove, A. Keddar, J. Griggs, C. Beets, P. Bemelmans, and P. Boermans, "Optimization of NDA Measurements in Field Conditions for Safeguards Purposes," Studiecentrum voor Kernenergie CEN/SCK. Mol, Belgium, report BLG 553 (January 1982).

3. M. S. Krick and H. O. Menlove, "High-Level Neutron Coincidence Counter (HLNCC): USERS MANUAL," Los Alamos Scientific Laboratory report LA-7779-M (ISPO-53) (Jline 1979). 
A software program was written and tested during the present exercise at the BWR facility. Its purpose was to collect data in the cyclic mode and calculate the estimated standard suviation from the number of counts.

$$
v \%=\frac{\sqrt{(R+A)+A}}{R} \times 100 \%
$$

as well as the mean responses ( $T$ and $R$ ) and the observed scatter ( $S$ ), about the mean. At the end of $n$ runs (or cycles), the standard deviation for the total counting time is calculated from

$$
\frac{\sigma \%}{\sqrt{n}}
$$

The inspector has a comparison of

$\sigma \%$ (predicted deviation)

with

\section{S\% (observed scatter)}

at the time of the measurements.

In the program, subroutine $B$ is used for the passive measurement, and the passive coincidence results are stored for background subtraction in subroutine $C$, which is used for the active measurement. The background correction factors are written directly into the program and no entries are required from the 
user. A totals rate background from the assembly in the collar is taken as 45 counts/s for all of the assemblies and BWR collars. This value should not be changed as long as the present calibration constants are in use. This is true also for the passive background correction factor of 0.0138 . An example of the readout format is given in Table A-I.

Only two results from the data output are required for the mass analysis and these are

$$
R=81.0 \text { counts } / s \pm 0.90 \% \text { (typical) }
$$

for the active $\left({ }^{235}()\right.$ assay, and

$$
R=3.2 \text { counts } / 5 \pm 2.1 \%
$$

for the passive $\left({ }^{238} U\right)$ assay.

The program listing and explanation of the HP-97 Data Coilection and Statistical Analyses Program are given in Table A-II. The subprogram $D$ in the software has been updated (July 1982) to include the mass calculation with the power function $M=a R^{t}$ calibration curve, where $a=0.03177$ and $b=1.399$. These constants are appropriate for AmLi-93 and an $8 \times 8$ rod BWR assembly containing six rods with 4.4 wt\% $\mathrm{Gd}_{2} \mathrm{O}_{3}$. 


\section{Passive Mode}
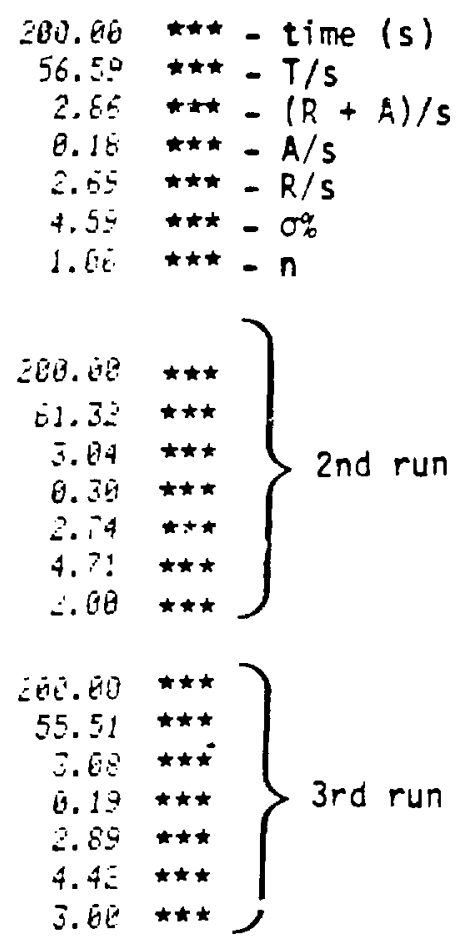

\section{Press B}

$$
\begin{aligned}
& 5 \therefore=+\cdots-\bar{T} / s \\
& \therefore S *-\bar{R} / s
\end{aligned}
$$

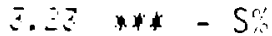

$2360.640 .6-238$

203 *a* $-\bar{R}$ corr.

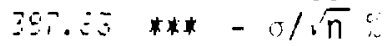

$\therefore-i \quad 01$

\section{Press D}

$$
\begin{aligned}
& 14.04 \star \star \star-M\left(a^{235} \mathrm{U} / \mathrm{cm}\right) \\
& 0.20 \star \star \star-A M(g) \\
& 3.04 \star \star \star *-\% U-235
\end{aligned}
$$

\section{Active Mode}
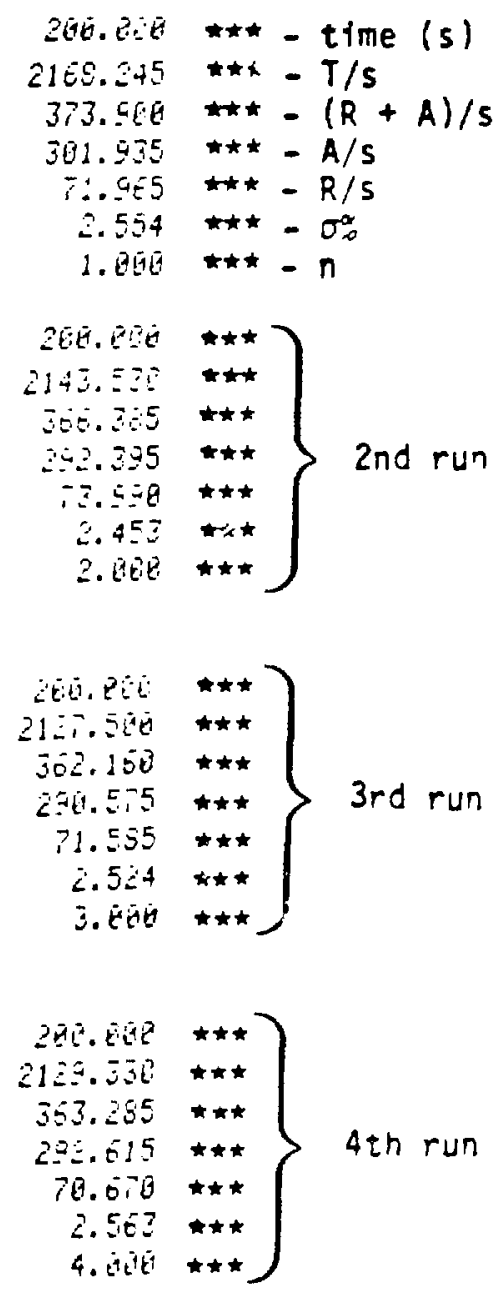

\section{Press C}

$$
\begin{aligned}
& 2136.734 * *-\bar{T} / \mathrm{s} \\
& 72.215 *-\bar{R} / \mathrm{s} \\
& 2.438+4-5 \% \\
& \therefore 35 E^{2}-\because L^{2}: 0 \quad-U-235 \\
& 0.583 \ldots * \vec{R} \text { net } \\
& 0.969+\sigma / \sqrt{n}
\end{aligned}
$$


TABLE A-I I

HP-97 DATA COLLECTION AND STATISTICAL ANALYSIS PROGRAM

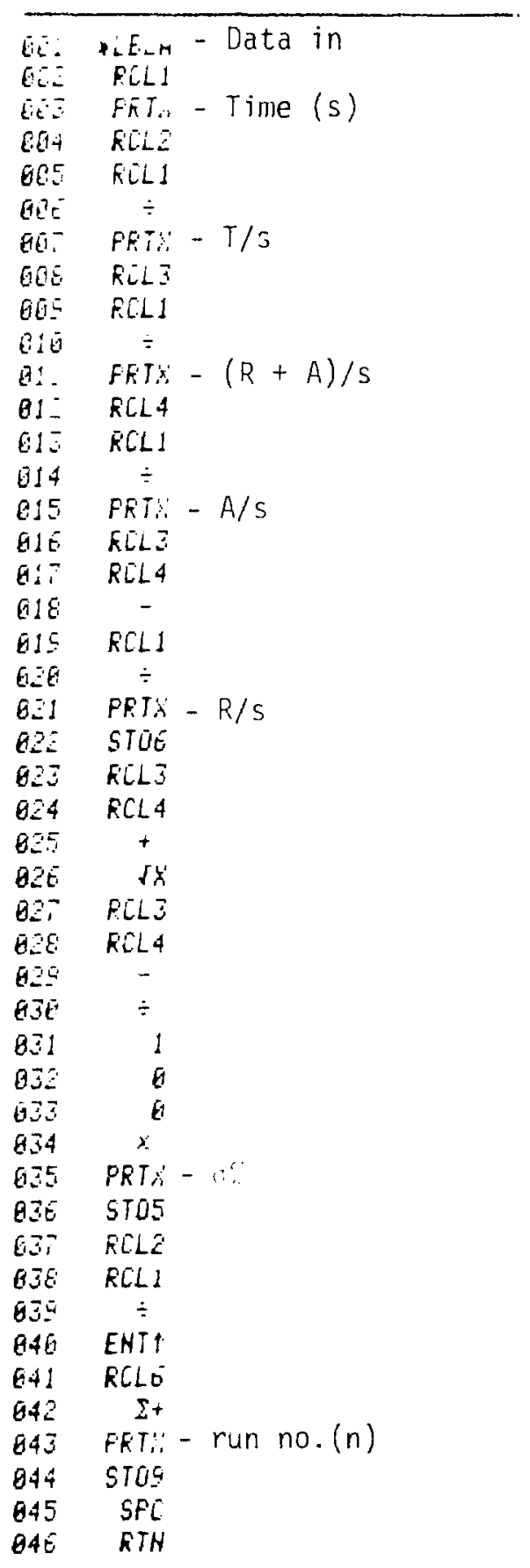


TABLE A-II (cont.)
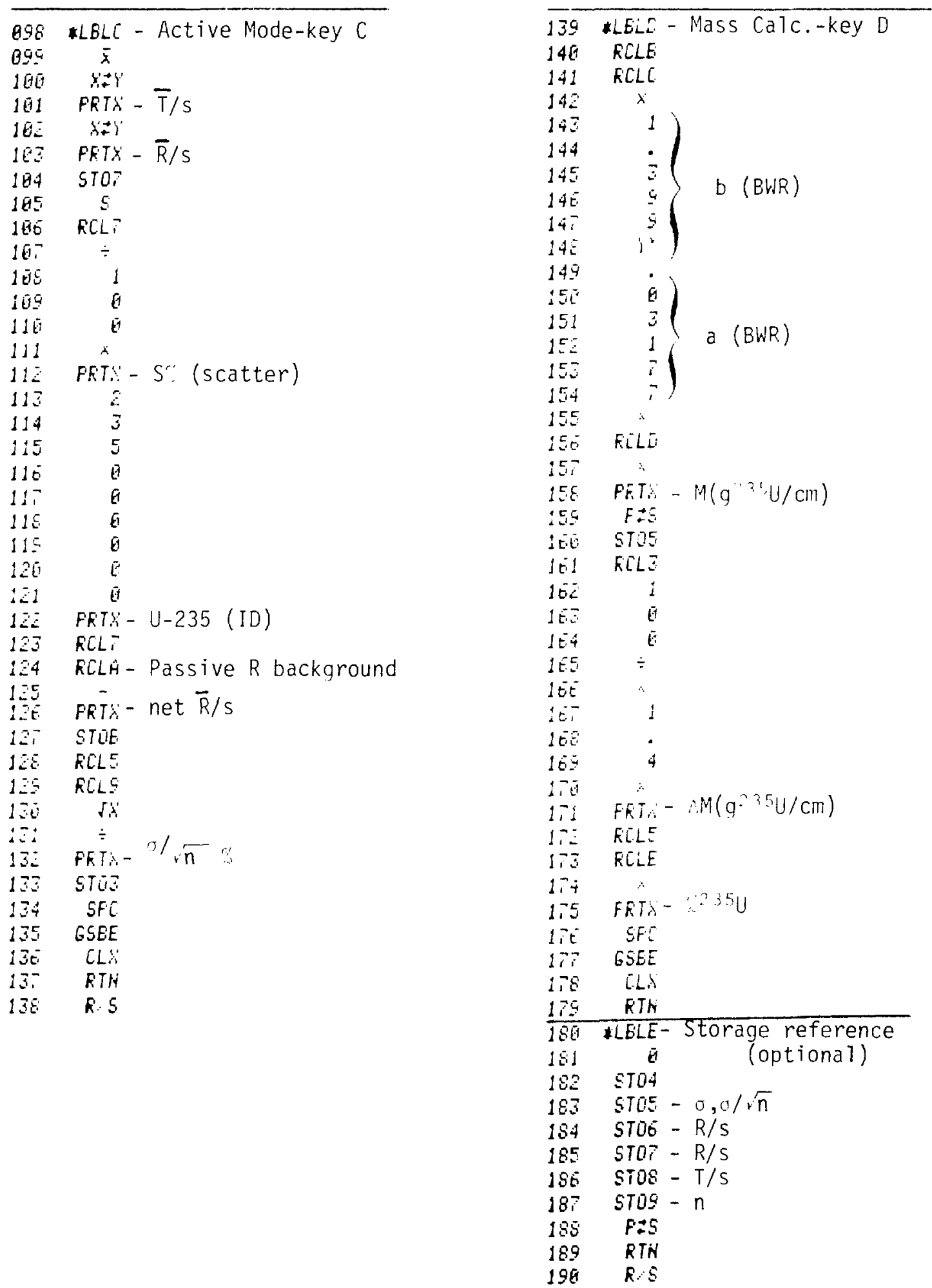


\section{APPENDIX B}

\section{CALIBRATION FOR $5 \times 5$ ROD ARRAYS}

The response functions given in Sec. VI apply only to $8 \times 8$ rod BWR assemblies. A series of measurements were performed to extend the calibration to $5 \times 5$ rod arrays. Rods were removed from the mockup assembly to obtain the $5 \times 5$ rod configuration shown in Fig. B-1. The average enrichments and masses for this reduced loading are given in Table $B-I$.

For the measurements, the assembly was positioned in the collar so that the plastic bagging around the zircaloy channel was just touching the inside face of the polyethylene in the collar. The coincidence responses for the two enrichments are 1 isted in Table $V$, and Fig. B- 2 shows a plot of the results $v$ s enrichment. None of the rods contained $\mathrm{Gd}_{2} \mathrm{O}_{3}$, so there is no difference between the bottom and top rates. The $8 \times 8$ response is shown on the same giaph for comparison.

If the responses are compared in terms of $\mathrm{g}^{235} \mathrm{U} / \mathrm{cm}$ rather than per cent enrichment, the differences beiween different type assemblies are less. Actually, the instrument measures the fissile loading per unit length. Figure B-3 shows the $5 \times 5$ results together with $8 \times 8$ data plotted as a function of loading per unit length. The $6 \times 6$ array results were obtained at Los Alamos before shipping the collar to the IAEA. In this case, all of the configurations fall on a common calibration curve.

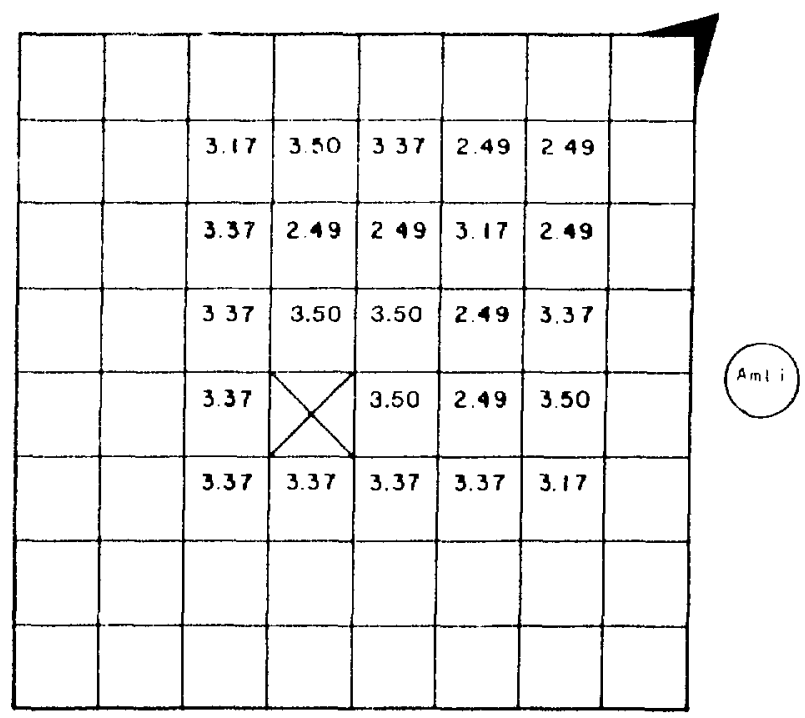

Fig. B-1.

Rod loading configuration for the $5 \times 5$ rod array with an average enrichment of $3.12 \% 235 \mathrm{U}$. The AmLi circle indicates the orientation of the neutron interrogation source. 


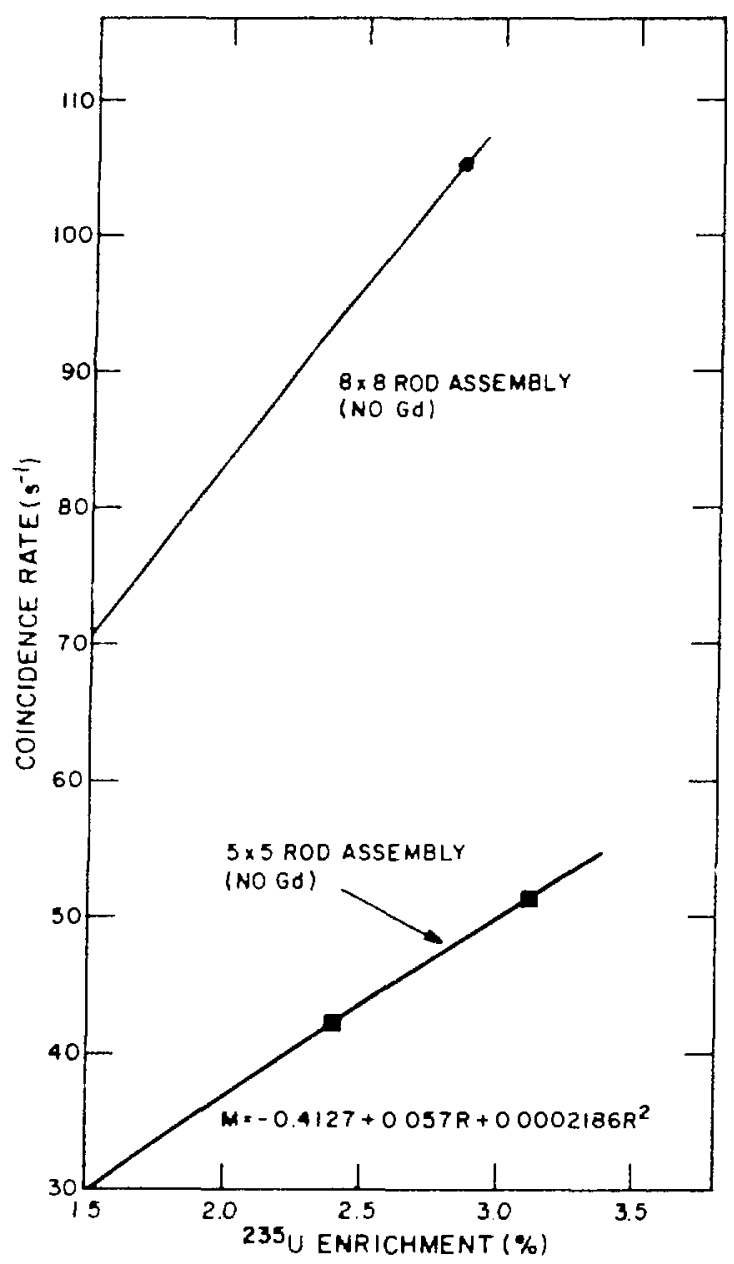

Fig. B-2.

Plot of the coincidence rate as a function of $235 \mathrm{U}$ enrichment for the different arrays.

Fig. B-3.

Plot of the coincidence rate as a function of $\mathrm{g} 235 \mathrm{U} / \mathrm{cm}$ for different rod arrays.

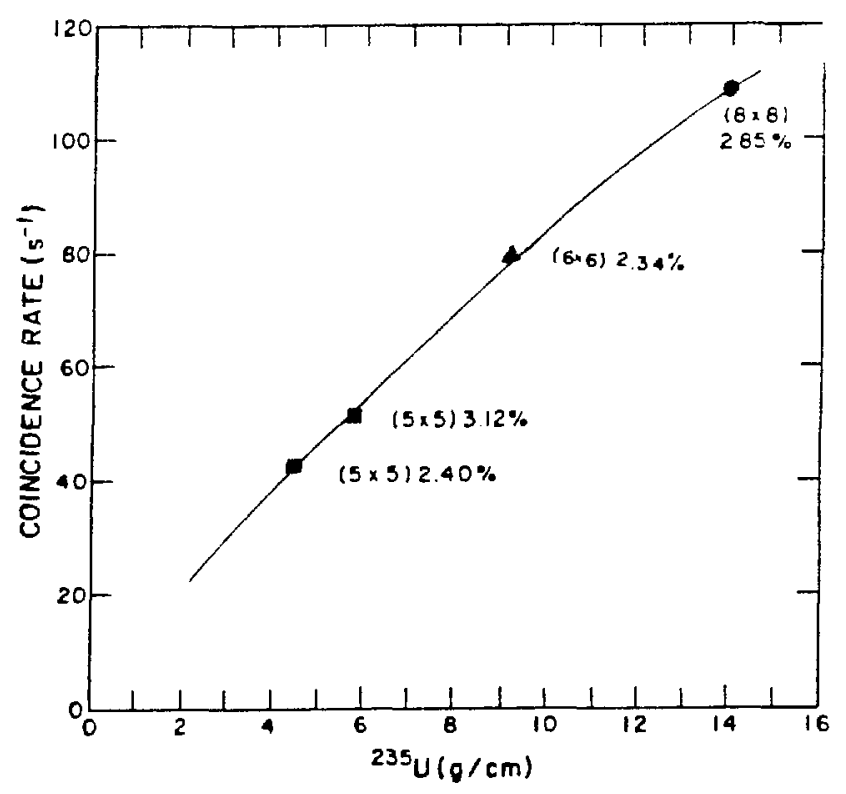


The calibration constants for the $5 \times 5$ rod array are given in the equation

$$
M=-0.4127+0.05757 R+0.0002186 R^{2} .
$$

These constants are for ${ }^{235} U$ enrichment when using Coincidence collar-3 (MRC-AmLi-93), where the source totals rate is 2160 counts/s. The same normalization procedure described in Sec. VI can be used to relate these coefficients to future measurements.

Table B-I gives the results for the different number of rods in the array together with the loading in terms of $\mathrm{g}{ }^{235} \mathrm{U} / \mathrm{cm}$. Note that the fuel pellet diameter for the $6 \times 6$ rod mockup at Los Alamos was $14.2 \mathrm{~mm}$ compared with an average of $10.3 \mathrm{~mm}$ for the ASEA-ATOM rods. None of these assemblies contained gadoi inium rods.

TAELE B-I

MEASUREMENT RESULTS FOR DIFFERENT BWR ROD ARRAYS

\begin{tabular}{|c|c|c|c|c|c|c|c|}
\hline As sembly & Array & $\begin{array}{l}\text { No. of } \\
\text { Rods }\end{array}$ & $\begin{array}{l}\text { Average } \\
\text { Per Cent } \\
235_{U} \\
\end{array}$ & $\begin{array}{l}238 \mathrm{U} \\
\mathrm{g} / \mathrm{cm}\end{array}$ & $\begin{array}{l}235 \mathrm{U} \\
\mathrm{g} / \mathrm{cm}\end{array}$ & $\begin{array}{l}\text { Coincide } \\
\text { Passive }\end{array}$ & $\begin{array}{l}\text { Ice Rate } \\
\text { Active } \\
\end{array}$ \\
\hline Mockup B & $5 \times 5$ & 24 & 2.40 & 178.9 & 4.44 & -- & 72.12 \\
\hline Mockup A & $5 \times 5$ & 24 & 3.12 & 180.3 & 5.76 & 0.93 & 51.35 \\
\hline Mockup F & $8 \times 8$ & 63 & 2.85 & 471.1 & 13.82 & 3.2 & 105.3 \\
\hline $\begin{array}{l}\text { Los Al amos } \\
\text { Mockup }\end{array}$ & $6 \times 6$ & 36 & 2.34 & 382 & 9.15 & 2.51 & 79.4 \\
\hline
\end{tabular}

